\title{
MUSICAL APTITUDE AND FOREIGN LANGUAGE RECEPTIVE PRONUNCIATION
}

\author{
Andrés Pujazón Rodríguez \\ Universidad de Huelva, Spain \\ andres.pujazon@alu.uhu.es \\ https: / / orcid.org/0000-0003-4070-4080
}

Received: 09/06/2021 I Accepted: 29/11/2021

Recommended citation:

Pujazón, A. (2021). Musical Aptitude and foreign language receptive pronunciation. Phonica, 17, 72-89. https://doi.org/10.1344/phonica.2021.17.72-89

\begin{abstract}
There is a growing body of literature that recognises the relationship between musical aptitude and language proficiency. Language is usually segmented into its subcategories when addressed in studies, while music is not. Due to this, it is unclear whether language proficiency is related to all music components (pitch, rhythm, etc.) in the same way. The purpose of this paper is to analyse the relationship between musical aptitude and receptive pronunciation in a foreign language, in this case, English. To achieve it, a field research study has been designed, in which participated 69 second grade 7-8-year-old students (34 boys and 35 girls) from a bilingual public school. Two tests were administered to measure their musical aptitude and their ability of discriminating phonemes. The musical test consisted of six exercises that assessed the different sub-skills of musical aptitude (pitch, loudness, duration, rhythm, timbre and tempo perception). On the other hand, the pronunciation test measured their auditory ability to differentiate phonemes in a foreign language. Our results show a positive correlation between musical aptitude and the identification of foreign language sounds.
\end{abstract}

Keywords: Musical aptitude; Pronunciation; Field research; Foreign Language.

(C) 2021 The authors. This is an open access paper under the Creative Commons 4.0 International (CC CBY 4.0) license, which allows the article's reproduction, distribution and public communication, whenever authorship and the journal's title is quoted. 


\section{Aptitud musical y pronunciación receptiva en lengua extranjera}

Resumen: Existe creciente evidencia en la literatura que reconoce la relación entre aptitud musical y competencia lingüística. La lengua se suele segmentar en sus subcategorías cuando se aborda en los estudios, mientras que la música, no. Debido a esto, no está claro si la competencia lingüística se relaciona con todos los componentes musicales (tono, ritmo, etc.) del mismo modo. El objetivo de este trabajo es analizar la aptitud musical y la pronunciación receptiva extranjera, en este caso, en inglés. Para ello, se ha llevado a cabo un estudio de campo en el que han participado 69 estudiantes españoles de $2^{\circ}$ de Primaria de un colegio público bilingüe, de 7 a 8 años de edad (34 niños y 35 niñas). Se administraron dos pruebas para medir su aptitud musical y su capacidad de discriminar fonemas. La prueba musical constaba de seis ejercicios que evaluaban las distintas subdestrezas de la aptitud musical (tono, amplitud, duración, ritmo, timbre y percepción de velocidad). Por otro lado, la prueba de pronunciación se basaba en la discriminación de fonemas. Los resultados muestran una correlación positiva entre la aptitud musical y la identificación de sonidos en lengua extranjera.

Palabras clave: Aptitud musical; Pronunciación; Estudio de campo; Lengua extranjera.

\section{Aptitud musical i pronunciació receptiva en llengua estrangera}

Resum: Hi ha una evidència creixent en la literatura que reconeix la relació entre aptitud musical i competència lingüística. La llengua se sol segmentar en les seves subcategories quan s'aborda en els estudis, mentre que la música, no. A causa d'això, no és clar si la competència lingüística es relaciona amb tots els components musicals (to, ritme, etc.) de la mateixa manera. L'objectiu d'aquest treball és analitzar l'aptitud musical i la pronunciació receptiva estrangera, en aquest cas, en anglès. Per a això, s'ha dut a terme un estudi de camp en el qual han participat 69 estudiants espanyols de $2 \mathrm{n}$ de Primària d'un col·legi públic bilingüe, de 7 a 8 anys d'edat (34 nens i 35 nenes). Es van administrar dues proves per a mesurar la seva aptitud musical i la seva capacitat de discriminar fonemes. La prova musical constava de sis exercicis que avaluaven les diferents subdestreses de l'aptitud musical (to, amplitud, durada, ritme, timbre i percepció de velocitat). D'altra banda, la prova de pronunciació es basava en la discriminació de fonemes. Els resultats mostren una correlació positiva entre l'aptitud musical i la identificació de sons en llengua estrangera.

Paraules clau: Aptitud musical; Pronunciació; Estudi de camp; Llengua estrangera. 


\section{Introduction}

The relationship between musical aptitude and language proficiency has become of interest in the last years (Milovanov, Huotilainen \& Välimäki, Esquef, Tervaniemi, 2007; Milovanov, 2009; Milovanov, Pietilä, Andrade \& Tervaniemi, 2010; Vangehuchten, Verhoeven \& Thys, 2015; Chobert \& Besson, 2013; Gómez-Domínguez, Fonseca-Mora, \& Machancoses, 2018). These studies analyse the similarities between the development of musical ability and different linguistic competences including: phonological awareness, phonemic awareness, sight identification, orthographic awareness, cueing systems awareness and fluency (Hansen \& Bernstorf, 2002, p. 20). In the language learning literature, the term "awareness" can be broadly defined as the faculty of recognizing and processing certain aural and written elements. Therefore, Hansen \& Bernstorf (2002) compares those skills related to text reading, music-symbol reading and music-text reading, and show that they are extremely similar. However, this paper does not concern language processing, but foreign language learning that also benefits from musical training.

In terms of reading capacity, Gomez, Fonseca \& Machancoses (2018) analysed the influence of musical aptitude on the acquisition of certain early foreign reading skills transferred from the first language. In other words, the study analysed whether musical perception influenced L1 early reading abilities. Furthermore, they concluded that those musically influenced reading competences remained in students' L2. The results showed positive transfer in some skills, among which phonological awareness can be highlighted, which is essential for our phonological awareness study.

For pronunciation, as it will be explained, students who have a higher musical aptitude tend to be more capable of processing and producing foreign sounds. One of the objectives of many studies (Vangehuchten et al., 2015; Milovanov et al., 2010) is to specify which students are those who show this correlation. This paper focuses on receptive pronunciation, which can be defined as degree of proficiency when processing language sounds. More specifically, the field research has been designed to assess a particular aspect of receptive pronunciation, which is phonological awareness, or the faculty of detecting and manipulating specific phonetic units of language (Culp, 2017; Peynircioglu, Durgunoglu \& Küsefoglu, 2002)

Previous studies have shown a positive relationship between pronunciation and musical aptitude (Gupta, Grunberg \& Rao, 2017; Milovanov et al., 2007; Milovanov et al., 2010; Vangehuchten et al., 2015). However, the profile of these studies does not concern the Spanish context, and tended to outperform non-musical instructed students in pronunciation tests. However, the purpose of this work does not concern musically instructed students. Our goal is to know if an untrained good ear for music equals a good ear for pronunciation, that is to say, if foreign language students belonging to a mainstream classroom that have not received thorough music education may benefit from their musical aptitude, which is a range of inherent abilities for music that an individual is born with and that are possibly shaped by informal exposition to music (Foncubierta, Machancoses, Buyse and Fonseca-Mora, 2020).

In order to have a clear first image, Fonseca-Mora (2011, p. 2), gathering from the considerable amount of literature that has been published on the differences and similarities between music and language, provides a general overview which is useful to establish as a starting point. Some of the similarities are:

(i) Both are universal and specific for human being.

(ii) Both are developed at the same time (isochronous).

(iii) Both share the same natural environment: auditory and vocal.

(iv) Emotional expression is essential in both domains. 
And some differences:

(i) Music cannot be "translated".

(ii) The range of musical styles evolve quickly in comparison to the grammar of a language.

(iii) While language asks about the real world (referential meaning), music does not have this function.

(iv) Musical rules do not provide meaning whereas grammar provides meaning to language.

Although there may be many other descriptive similarities, it is not clear whether general musical aptitude matches with a specific subcomponent of language (phonetics, syntax, etc.). In relation to this, music is not usually approached in terms of each of its subcomponents (pitch, rhythm, duration, etc.), but as a whole. The only example we have found is Christiner \& Reiterer (2013), and their follow up work (Christiner \& Reiterer, 2018). However, there is still more demand for studies on the comparison between musical aptitude and phonological awareness specifically, since they provide crucial information that contribute to polish the findings and clearly see which component of musical aptitude is relevant to this aspect of receptive pronunciation.

\subsection{Objectives}

This study aims to achieve the following objectives:

1. The main specific objective is to find out if there is a correlation between musical aptitude and pronunciation in Spanish children studying English as a foreign language who have not received musical instruction.

2. The more exhaustive objective is to observe how the different components of musical aptitude, that is to say, pitch, loudness, duration, rhythm and tempo ${ }^{1}$, relate to phonological awareness.

\section{Theoretical Framework}

\subsection{Concept of musical aptitude, musicality and phonological awareness}

The term musical aptitude is usually defined from two different points of view. GómezDomínguez et al. (2018) quote Levinson for the nurturing perspective and Trehub for the nativist perspective. In fact, Foncubierta, Machancoses, Buyse and Fonseca.Mora (2020) define musical aptitude as a range of inherent abilities for music that an individual is born with and that are possibly shaped by informal exposition to music. In other words, musical aptitude is an innate capacity that may develop depending on the environment, it is a very similar case to language. However, this definition does not imply that non-musician people do not have musical aptitude: Law \& Zentner (2012) explain the necessity of assessing this skill through an objective test, since being musician does not guarantee having musical aptitude: "Prima facie support for the distinction between musical potential and musical training comes from the common observation that individuals with the same degree of musical acculturation appear to differ in their musical capacities" (Law \& Zentner, 2012, p. 2). This would mean that a person can have musical aptitude even though he or she has never nurtured it, because "some people might reach a high level of musical proficiency if given the time and opportunity to do so" (Law \& Zentner, 2012, p.1). In addition, Law \& Zentner (2012) introduced the reception/production dichotomy. A key point for

\footnotetext{
${ }^{1}$ Timbre was omitted for reasons explained in the practical comment of results.
} 
understanding the correlations between musical aptitude and language is differentiating receptive from productive abilities since, as it will be explained further on, both types of abilities may not agree, since a person may have an excellent receptive pronunciation, but not be able to produce it at the same level. Law \& Zentner based their test on receptive musical aptitude, which does not concern productive capacities such as playing an instrument or singing (Law \& Zentner, 2012, p. 4).

Relating to the concept of musical aptitude, it is also convenient to observe its different subcomponents. Musical aptitude can be segmented into "tempo, pitch, rhythm, timbre, melody perception, or any combination of these" (Law \& Zentner, 2012, p. 1). Applied to the context of this essay, musical aptitude and pronunciation will be compared, but they will be segmented into their several items.

On the other hand, musicality is a more general term. It refers to the rhythmic and tonal components of language which resembles music: each language has a different rhythm (Patel \& Daniele, 2002, p. 35), and intonation, which creates the melody of speech (Cantero, 1998, p. 36). Matching to Law \& Zentner's (2012) study in a very simplistic way, musical aptitude and language would be the starting point of comparison, but the sub-competences that are being compared are rhythm/intonation and prosody respectively. It is worth mentioning that this term is very ambiguous when found in literature. For instance, Vangehuchten (2015) uses the term for general musical capacities, such as performances, improvisations, etc. (Vangehuchten, 2015, p. 90), or, as it has been mentioned, Cantero (1998) refers to musicality as intonation, which is what creates that melody of speech (Cantero, 1998, p. 36). For this reason, it must be warned that this term can be used either as a general or a specific competence. This paper focuses on phonological awareness, which can be defined as "a person's ability to analyse and manipulate the sounds of language, including units within words and/or entire words" (Culp, 2017, p. 329). Thereby, this term refers mainly to receptive capacities and has been connected to receptive musical aptitude. As it has been mentioned, a key point in this discussion is the paradigm of receptive and productive competences. Law \& Zentner (2012) created their test addressing only receptive parts. Both language and musical testing can refer to reception and production, but tests obviously have radically different designs.

Beginning from an intuitive point of view, phonological awareness shares common features with receptive musical aptitude (at least sub-items such as tone or timbre), since both address capacities of processing and distinguishing sounds. Based on this idea, literature started studying the relationship between musical aptitude (and/or their sub-competences) and phonological awareness (Culp, 2017; Peynircioglu, Durgunoglu \& Küsefoglu, 2002). Literature on this topic tends to agree with the correlation between phonological awareness and musical aptitude, especially with the subdomain of pitch (Culp, 2017, p. 332).

Literature also pays attention to the previous training of the participants when the correlation between musical aptitude and phonological awareness is studied since musical expertise can also benefit phonological awareness. Furthermore, some studies study the correlation when the participant (normally children) simply uses to perform musical activities, instead of having solid musical expertise, drawing positive correlations results (Culp, 2017, p. 333). The receptive/productive paradigm is another essential dichotomy which depends on the previous musical background of the participant.

\subsection{Field Research comparison: instructed and uninstructed participants}

Publications that concentrate on the correlation between pronunciation and music are largely based upon field research studies that compare different participants with different musical aptitude or pronunciation perception. When choosing the profiles of the participants, many studies 
pay special attention to their musical expertise (Milovanov, 2007): they show whether musical nurturing affects language skills. More recent studies (Vangehuchten et al., 2015; Christiner \& Reiterer, 2018) work with participants that have not received a musical instruction: they approach the connection between music and language in a much more natural way. These studies complement traditional instruction-based ones since they approach the correlation from a different perspective: they attempt to evaluate the influence of innate (instead of trained) musical aptitude in pronunciation. Therefore, the verification of one perspective does not imply the negation of the other, since their participants are different.

A key point in the discussion is the difference between productive and receptive linguistic competences. As to say, phoneme discrimination would be a receptive competence, while pronunciation involves production. As it is going to be explained, the correlations do not necessarily have to coincide: it is possible to have a positive correlation in musical aptitude and receptive pronunciation, and a negative in musical aptitude and productive pronunciation.

\subsubsection{Instructed participants}

\section{Receptive pronunciation}

Chobert \& Besson (2013) recalls different studies that implied pitch and duration: in the pitch test, the participants heard a musical and a linguistic phrase, in which the final note/word was slightly higher pitched. The musical phrase would then have its "final note increased by $1 / 5$ or $1 / 2$ of a tone and the f0 contour of the final words was increased by $35 \%$ or $120 \%$ (suprasegmental changes) $)^{2 "}$ (Chobert \& Besson, 2013, p. 925). In the duration test, the sentences had its final syllable lengthened, and the participants had to notice it, first, and decide then whether it affects the meaning of the sentence. In fact, in both tests musician participants outperformed nonmusician. Furthermore, similar results appeared in children, which is a very important fact for the discussion, since field researchers try to take into account the larger profile of participants as possible, and so does this study. To sum up, people who have received musical training for pitch and rhythm, tend to have a better phonological awareness in the tests they are given, since the abilities they exercise are the same for both linguistic and musical activities.

Although Chobert \& Besson (2013) and Milovanov et al. (2009) recall studies that showed positive connections in adults and children, we cannot assert a clear rule since the variety of results is noticeable in both profiles. Milovanov's study (2010) produced some interesting results. Dealing with adults, the field research was arranged in a standard way: they were assessed by Seashore musical aptitude test which assessed Pitch, Loudness, Rhythm, Time, Timbre and Tonal Memory, and then they were asked to do a phonemic discrimination test ${ }^{3}$ to show if a better musical aptitude implied a better performance in the other test. Surprisingly, Milovanov obtained the following results, illustrated by this graph (see graph 1).

The test consisted in recognising phonemic contrasts, similar to what we have done in our field research. As we see, all profiles of participants made a similar performance in the receptive pronunciation test. Obviously, the English students are supposed to have had a relevant instruction on language, and so do choir members on music. This means that we are dealing again with instructed participants. These results would point that there is no strong relationship between musical expertise and receptive pronunciation proficiency. As to say, practicing music does not improve our ear for language. However, as we have already seen, many other results differ from Milovanov (2010) in this sense.

\footnotetext{
${ }^{2}$ This f0 contour refers to the final rising intonation of some utterances that change the meaning of the sentence, which is a pragmatic feature of languages as English or Spanish, but also essential and linguistically meaningful in some languages such as Japanese or Mandarin Chinese (Fujisaki, 1988).

${ }^{3}$ In this study, a productive pronunciation test was included as well.
} 


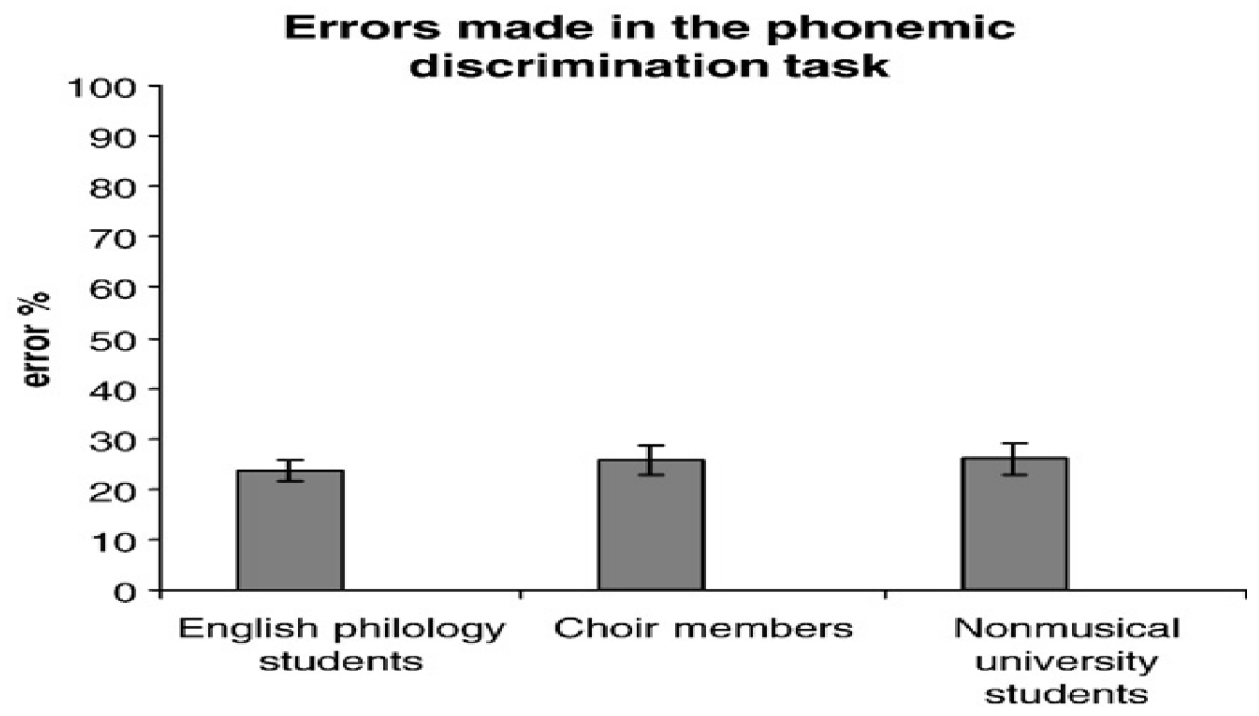

Graph 1. Milovanov's results on phonemic awareness. Milovanov. (2010, p. 58)

In relation to those studies that choose children as participants, Gómez-Domínguez et al., (2018, p. 3) recalls a study which show that musical training does not affect phonological awareness: "The present data provides no support for our first hypothesis that a musical training in the penultimate year of preschool leads to substantial gains in phonological awareness" (Kempert, Götz, Blatter, Tibken, Artelt, Schneider \& Stanat, 2016, p. 13). Thus, some controversy exists when the connection perceptive/productive pronunciation is considered and whether participants are children or adults.

\section{Productive pronunciation}

The hypothesis "musical expertise influences productive pronunciation" is supported by many experts. However, the results are not consistent enough to assert an irrefutable connection. For instance, according to Chobert \& Besson (2013, p. 928): "Investigations of the perception and/or production relationship in non-native languages are centred on the issue of whether performance in one domain influences the other domain (...) musical expertise not only influenced the perception, but also the production of new phonological contrasts". Milovanov et al. (2010) also reached the same conclusion: musical aptitude and productive pronunciation are correlated, although the following graph is worth mentioning (see graph 2):

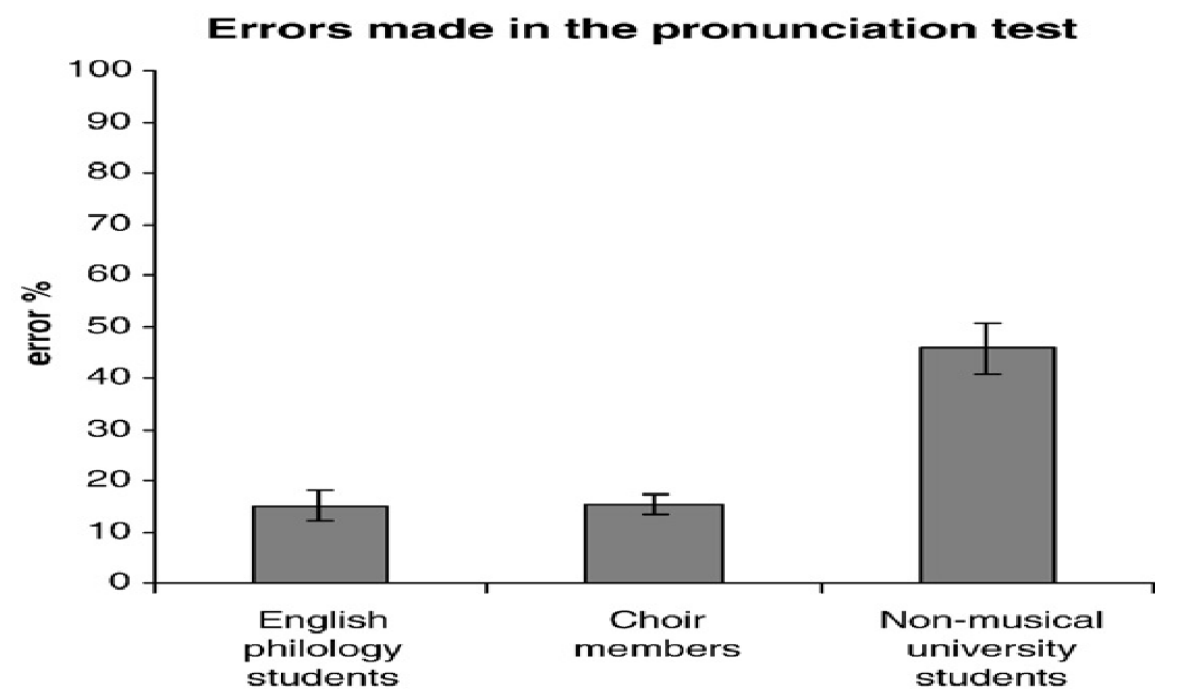

Graph 2. Milovanov's results on productive pronunciation. Milovanov. (2010, p. 58) 
As it can be appreciated in the graph, the difference between non-musical and musical participants is noticeable. This would mean that participants that have had a previous instruction in music (choir members) tend to perform better in productive pronunciation than non-musical participants, which would then mean that music training enhances pronunciation.

However, there are some studies that maintain the discussion, since their works produced other results (Kang \& Williamson 2013; Pei, Wu, Xiang, \& Qian, 2016). Kang et al. (2013) did not obtain a correlation between music training and productive pronunciation, but the authors argue that the mismatch could come from the length of time: "The apparent discrepancy in findings could be explained by the fact that the previous studies typically relate perception and production skills after much longer periods of L2 learning than possible to examine in the present study. It may be that musicality, by the present definition, has little impact on short-term L2 learning" (Kang, 2013, p. 738). Regarding Pei et al. (2016), they discovered a connection between musical training and suprasegmental pronunciation, but they did not obtain a correlation between musical training and other areas of productive pronunciation (Pei et al., 2016, p. 23).

Again, when it comes to children, Posedel, Emery, Souza and Fountain (2012), concluded that the only musical training which influenced productive pronunciation was pitch recognition (Posedel et al., 2012, p. 15). On the other hand, Milovanov (2007, p. 85) affirms: "Based on our findings, we propose that language skills, both in production and discrimination, are interconnected with perceptual musical skills" Once again, there still are some discrepancies.

Before moving on to uninstructed participants, Table 1 summarises the different results that have been commented. It includes both dichotomies that have been observed when approaching the relationship between musical aptitude and receptive pronunciation, and organises the different studies depending on the result they have obtained:

\begin{tabular}{|c|c|c|}
\hline & Children & Adults \\
\hline $\begin{array}{l}\text { Receptive } \\
\text { pronunciation }\end{array}$ & $\begin{array}{l}\text { Correlation: Chobert \& Besson } \\
\text { (2013) } \\
\text { No correlation: Kempert et al. } \\
\text { (2016) }\end{array}$ & $\begin{array}{l}\text { Correlation: Chobert \& Besson } \\
\text { (2013) } \\
\text { No correlation: Milovanov et al. } \\
(2010)\end{array}$ \\
\hline $\begin{array}{l}\text { Productive }^{4} \\
\text { pronunciation }\end{array}$ & $\begin{array}{l}\text { Correlation: Milovanov et al. } \\
\qquad \text { (2007) } \\
\text { No correlation: Posedel et al. } \\
\text { (2012) }\end{array}$ & $\begin{array}{l}\text { Correlation: Chobert \& Besson } \\
\text { (2013), Milovanov et al. (2010), } \\
\text { No correlation: Kang \& Williamson } \\
\text { (2013), Pei et al. (2016) }\end{array}$ \\
\hline
\end{tabular}

Table 1. Varieties of results in the correlation of music and pronunciation.

\subsubsection{Uninstructed participants}

Understanding the differences between instructed and uninstructed participants will allow to establish the boundaries within the correlation. Due to this, the division of both approaches has two main reasons. Firstly, the authors explicitly specify whether the participants have received instruction (Vangehuchten et al., 2015; Milovanov, 2009; Milovanov et al., 2007) so it is sensible

\footnotetext{
${ }^{4}$ Besson, Barbaroux \& Dittinger (2017) do find a correlation between musicality and productive pronunciation in adults, but we have not included it since those tests were performed for native languages, not for foreign languages (Besson, 2017, p. 932)
} 
to check the results separately. Second, it is interesting to leave instruction aside, to try to study the purest connection between language and music, in order to show whether they are connected from the very beginning. Kuhl (2004) narrates an experiment in which babies were exposed to pieces of speech, and they reacted to certain intonation patterns or frequencies. For this reason, it is also interesting to show if a natural good ear for music means a natural good ear for language (Vangehuchten, 2015), instead of studying whether nurturing music also nurtures language. As it has been explained in the introduction of this section, both lines do not contradict one another.

This complementary line of research analyses the connection in people who have not had a previous instruction in music, so this point of view does not concern the nurture aspect. Vangehuchten et al. (2015) performed a study in Belgium, with 29 students of Spanish as a foreign language. For the musical part, Vangehuchten et al. (2015) arranged two tests: Seashore Musical Test for the receptive musical aptitude, and a productive musical part as well ${ }^{5}$. For the pronunciation part, there were also two exercises, which were a phoneme discrimination for the reception and a repetition of words and sentences for the production.

As it has been commented, this research coincides with Milovanov et al. (2010), except for the musical instruction of the participants: in Milovanov's study, choir members were evaluated, while in Vangehuchten et al. (2015), participants had no previous musical instruction (which does not mean they do not have musical aptitude, as we have seen previously).

As described in the previous section, we find that the productive and receptive results differ from one another. In the receptive part, "having a good ear for music is correlated with having a good ear for language, and vice versa" (Vangehuchten et al., 2015, p. 95). This matches most part of the results of instructed participants. However, moving on to the productive part, participants with high musical aptitude did not outperform those with less aptitude in productive pronunciation. There was no apparent correlation between listening aptitude and productive competences, nor in pronunciation or music. As a result, it can be noticed that the correlation in reception of music and phonological awareness is positive, but once we move on to production, boundaries remain unclear.

\section{Methodology}

The main objective of this study is to find out if there is a correlation between musical aptitude and pronunciation in Spanish children studying English as a foreign language who have not received musical instruction. Besides, it is detailed how the different components of musical aptitude, that is to say, pitch, loudness, duration, rhythm and tempo relate to phonological awareness.

\subsection{Participants}

69 second-grade students ( 34 boys and 35 girls, 7-8 years old) were selected from a bilingual primary school in a medium socio-economic and socio-cultural district in Spain. All the participants were native speakers of Spanish. All of them had started attending kindergarten at the age of three where they were taught Spanish as the language of instruction and English as a FL. Thus, they had the same educational background. In the second grade of primary education they received 2 hours in English per week. Regarding musical background, all students have received 2 years of compulsory music education at primary school, which is not too thorough. None of them had extracurricular musical activities.

\footnotetext{
${ }^{5}$ These results will be commented, but this essay does not deal with productive musical aptitude.
} 


\subsection{Instruments}

A test of music perception and a phonological awareness test in English language were administered to the participants. Instructions were given in Spanish language.

Music perception test. The music perception test by Hernández-Hernández and SantiagoGonzález (2010) was adapted for 7-8-year-old students for administration purposes. This is a measure of auditory processing aimed at evaluating the accuracy of auditory (receptive) discrimination skills within typically developing children. This test does not measure productive musical ability, such as singing or instrumental music performance, but takes into consideration the participants' receptive sensitivity to basic sound patterns varying in pitch, rhythm and timbre. It consists of six parts that measure different aspects of perceptual musical skills across the following dimensions: pitch, intensity, duration, rhythm, musical timbre and musical tempo (see table 2). Each correct answer scores one point and each incorrect one scores zero, and the maximum possible score is 35 points. During administration, two practice trials preceded each part to ensure that the children understood the task.

\begin{tabular}{|c|c|c|}
\hline & Items & Description \\
\hline Pitch discrimination & 6 & $\begin{array}{l}\text { Skills in discriminating higher or lower tones in pitch } \\
\text { by identifying rising and descending scales }\end{array}$ \\
\hline Intensity-loudness & 6 & $\begin{array}{c}\text { Skills in differentiating between strong and weak } \\
\text { tones. }\end{array}$ \\
\hline Duration & 6 & $\begin{array}{c}\text { Skills in differentiating between long and short } \\
\text { sounds }\end{array}$ \\
\hline Rhythm recognition & 6 & $\begin{array}{l}\text { Skills in recognising the duration of sounds in } \\
\text { different rhythmic patterns of } 4 \text { beats in length. } \\
\text { Students were required to draw the beats of each } \\
\text { note pattern on their sheet using points for faster } \\
\text { beats and lines for slower ones. }\end{array}$ \\
\hline Musical timbre & 3 & $\begin{array}{c}\text { Skills in identifying melodies presented in different } \\
\text { commonly heard timbres of musical instruments } \\
\text { (tone quality). }\end{array}$ \\
\hline Musical tempo & 8 & $\begin{array}{l}\text { Skills in discriminating the musical tempo of different } \\
\text { melodic sequences: slow, normal and fast. }\end{array}$ \\
\hline
\end{tabular}

Table 2. Musical test exercises (Gómez, Fonseca, Machancoses, 2018).

Phonological awareness test. A battery of 12 listening exercises was created and given to the participants. Each correct exercise is worth one point and mistakes are marked with 0 points. The activity consisted in circling the odd-one in a group of three words: the students heard three words, two of them were the same one and one of them was different. The difference lies in a single phoneme which does not exist in Spanish or is hard to detect in English for Spanish students. The students heard each exercise twice. The phonemes to differ were chosen by their phonological length and their place and manner of articulation. The idea was inspired by studies such as Vangehuchten et al. (2015), Milovanov et al. (2010), Milovanov et al. (2009) and Milovanov et al. (2007), but the stimulus material was adapted to vocabulary that 7-8-year-old children should know.

Statistical analysis. A two-variable correlation test, a simple regression analysis and a multiple regression analysis were used to quantify the relation between musical aptitude and its subdomains and phonological awareness. The latter was regarded as the dependant variable for both regression analyses. 


\subsection{Procedure}

The school community was informed and formal consent from the local administration was granted. Both tests were done on the same day, 30 minutes for the musical test and 15 for the phonological awareness test. The music perception test was administered collectively to the whole class. Musical stimuli were pre-recorded on a DVD and played in the classroom while students were completing the activities on a sheet. The listening exercises were pre-recorded with a text processor and played clearly for the whole class while they were circling the answer in their answer sheets.

\section{Results}

\subsection{Test results}

First, we will show the mean results of the musical aptitude test. They are separated by subdomains (see table 3). The minimum and the maximum columns show the lowest and the highest scores among all the participants, as to say, neither a student has scored 0 points nor 100 in any subdomain.

\begin{tabular}{|l|c|c|c|}
\hline & Mean score out of 100 & Minimum & Maximum \\
\hline Pitch & 75.85 & 0 & 100 \\
\hline Loudness & 89.37 & 0 & 100 \\
\hline Duration & 93.48 & 0 & 100 \\
\hline Rhythm & 36.71 & 0 & 100 \\
\hline Timbre & 60.39 & 0 & 100 \\
\hline Tempo & 88.77 & 25 & 100 \\
\hline
\end{tabular}

Table 3. Musical test results.

Regarding general scores, the mean score of the whole group was 75.86 . The minimum score obtained in the exam was 45.71 , while the maximum 97.14.

Pronunciation was assessed in a single score test. Unlike the musical aptitude test, this one was not itemised (see table 4). Instead, results show the average proficiency at discriminating the minimum pair.

\begin{tabular}{|l|c|c|c|}
\hline & Mean score out of $\mathbf{1 0 0}$ & Minimum & Maximum \\
\hline Total & 76.81 & 50 & 100 \\
\hline
\end{tabular}

Table 4. Pronunciation test results.

\subsection{Statistical analysis: variable correlation}

In order to analyse the correlations between the variables que have taken into account, we have used a two-variable correlation matrix. In this case, the contrast is unilateral since we are working with very specific hypotheses: high scores on each subdomain and each test correlates positively with high scores on our dependent variable (DV).

Table 5 shows that the musical aptitude test correlates positively and statistically $(r=0.335, p<$ 0.01 ) with the phonological awareness test. More specifically, pitch and duration correlates positively with phonological awareness $(\mathrm{r}=0.370, \mathrm{p}<0.01 ; \mathrm{r}=304, \mathrm{p}<0.01)$. 


\begin{tabular}{|l|l|l|l|l|l|l|l|l|c|}
\hline Variable & Pitch & Loudness & Length & Rhythm & Timbre & Tempo & $\begin{array}{c}\text { Musical } \\
\text { aptitude }\end{array}$ & $\begin{array}{c}\text { Phonological } \\
\text { awareness }\end{array}$ \\
\hline Pitch & &, 170 &,- 013 &, 045 & &, 072 &, 142 &, $527^{* *}$ &, $370^{* *}$ \\
\hline Loudness & & &, 032 &,- 052 & &, $227^{*}$ &,- 037 &, $453^{* *}$ &, 070 \\
\hline Duration & & & &, $217^{*}$ & &, 172 &, 010 &, $369^{* *}$ &, $304^{* *}$ \\
\hline Rhythm & & & & &, 070 &, 028 &, $586^{* *}$ &, 156 \\
\hline Timbre & & & & & & &,- 007 &, $426^{* *}$ &, 167 \\
\hline Tempo & & & & & & &, $401^{* *}$ &, 067 \\
\hline Musical & & & & & & & & &, $355^{* *}$ \\
\hline
\end{tabular}

Table 5. Two-variable correlation matrix.

\subsection{Statistical analysis: regression analysis}

Regression analysis quantifies the relation between a dependent quantitative variable and an independent or predictor quantitative variable. On this relation, we can build a lineal model which allows to see the impact of the independent variables on the dependent variables and prognosticate the dependent variable.

If we run a simple regression analysis in which the dependent variable is the pronunciation score and the independent variable is the musical aptitude score, we obtain the following lineal equations (see Table 6):

\begin{tabular}{|l|l|l|l|l|l|}
\hline & \multicolumn{1}{|c|}{$\boldsymbol{R}^{2}$} & $\mathrm{~B}$ & $\mathrm{SE}$ B & $\boldsymbol{\beta}$ & $\boldsymbol{P}$ \\
\hline Model 1 & 0,126 & & & & \\
\hline Constant & & 5,462 & 1,224 & & $<.001$ \\
\hline $\begin{array}{l}\text { Musical } \\
\text { aptitude }\end{array}$ & & 0,141 & 0,046 & 0,355 & $<.05$ \\
\hline
\end{tabular}

Table 6. Simple regression analysis.

Although the coefficients for this simple regression analysis show that phonological awareness variable is dependent of musical aptitude, square $\mathrm{R}$ value in the model summary shows that this model only takes into account $12.6 \%$ of the variability found in the dependent variable (phonological awareness). Therefore, there is a remaining $87.4 \%$ variance unexplained, so general musical aptitude is not enough to explain the results in phonological awareness.

On the other hand, multiple regression analysis allows us to delete the analysis of shared effects between the variables in order to notice the clear effect of each of them and judge their relevance: it shows to what extent each variable is able to explain the dependent variable behavior (phonological awareness). Results are shown in Table 7. 


\begin{tabular}{|l|c|c|c|c|c|}
\hline & $\boldsymbol{R}^{2}$ & $\mathrm{~B}$ & $\mathrm{SE}$ B & $\boldsymbol{\beta}$ & $\boldsymbol{P}$ \\
\hline Modelo 1 & 0,173 & & & & \\
\hline Constante & & 3,877 & 1,740 & & $<0.05^{*}$ \\
\hline Pitch & &, 385 &, 120 &, 366 & $<0.01^{* *}$ \\
\hline Loudness & &,- 019 &, 121 &,- 018 &, 874 \\
\hline Length & &, $\mathbf{5 7 3}$ &, 237 &, 277 & $<0.05^{*}$ \\
\hline Rythm & &, 056 &, 089 &, 072 &, 527 \\
\hline Timbre & &, 146 &, 184 &, 092 &, 429 \\
\hline Tempo & &, 012 &, 135 &, 010 &, 928 \\
\hline
\end{tabular}

Table 7. Multiple regression analysis.

Results show that phonological awareness can be predicted by pitch $(\beta=0,366, \mathrm{t}=3,22, \mathrm{p}<0.01$, IC95\% $=[0.146,0.624])$ and duration $(\beta=0.277, \mathrm{t}=2,42, \mathrm{p}<0.05$, IC95\% $=[0,100,1,046]$. These results are illustrated by the following graphs 3 and 4 :

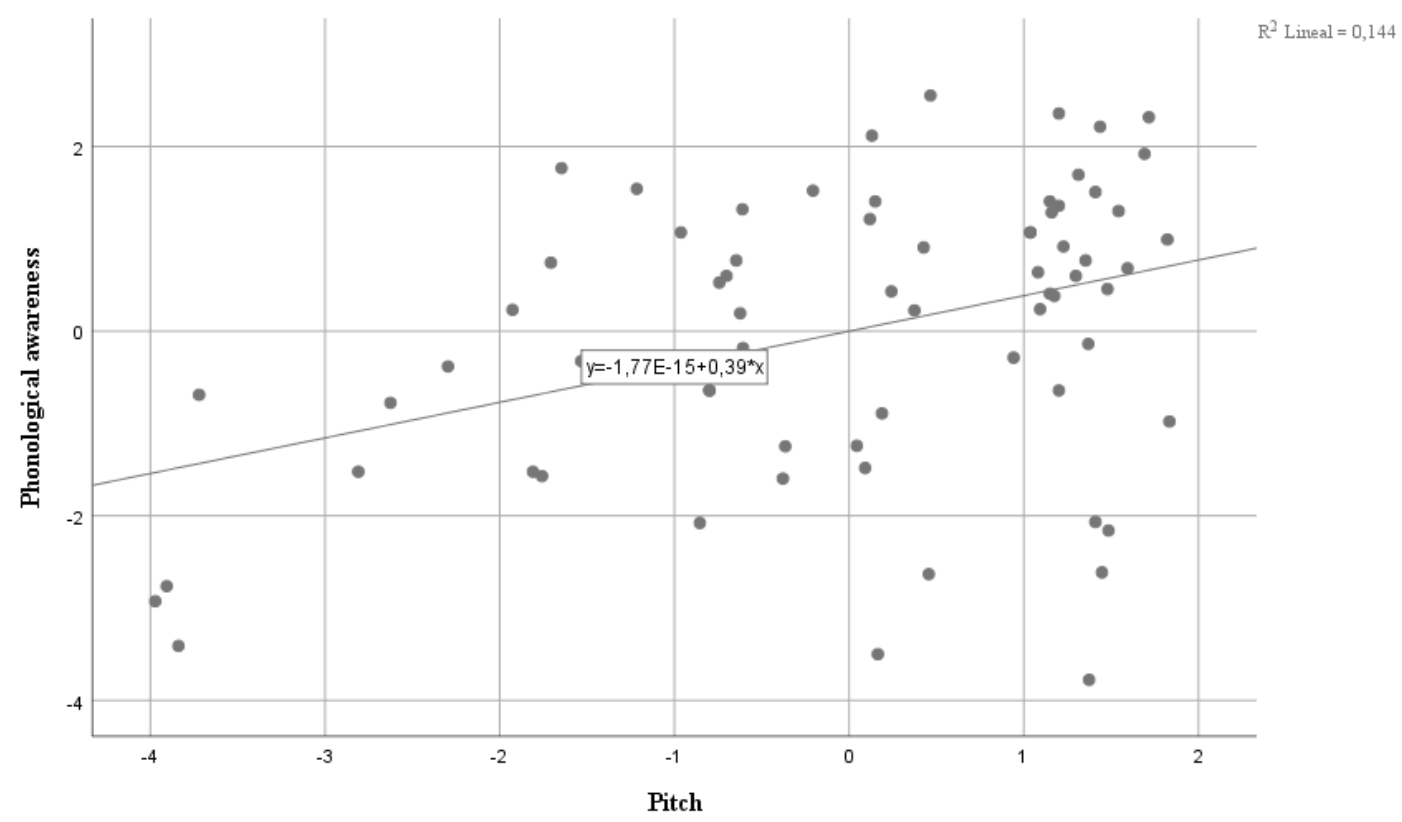

Graph 3. Phonological awareness and pitch. 


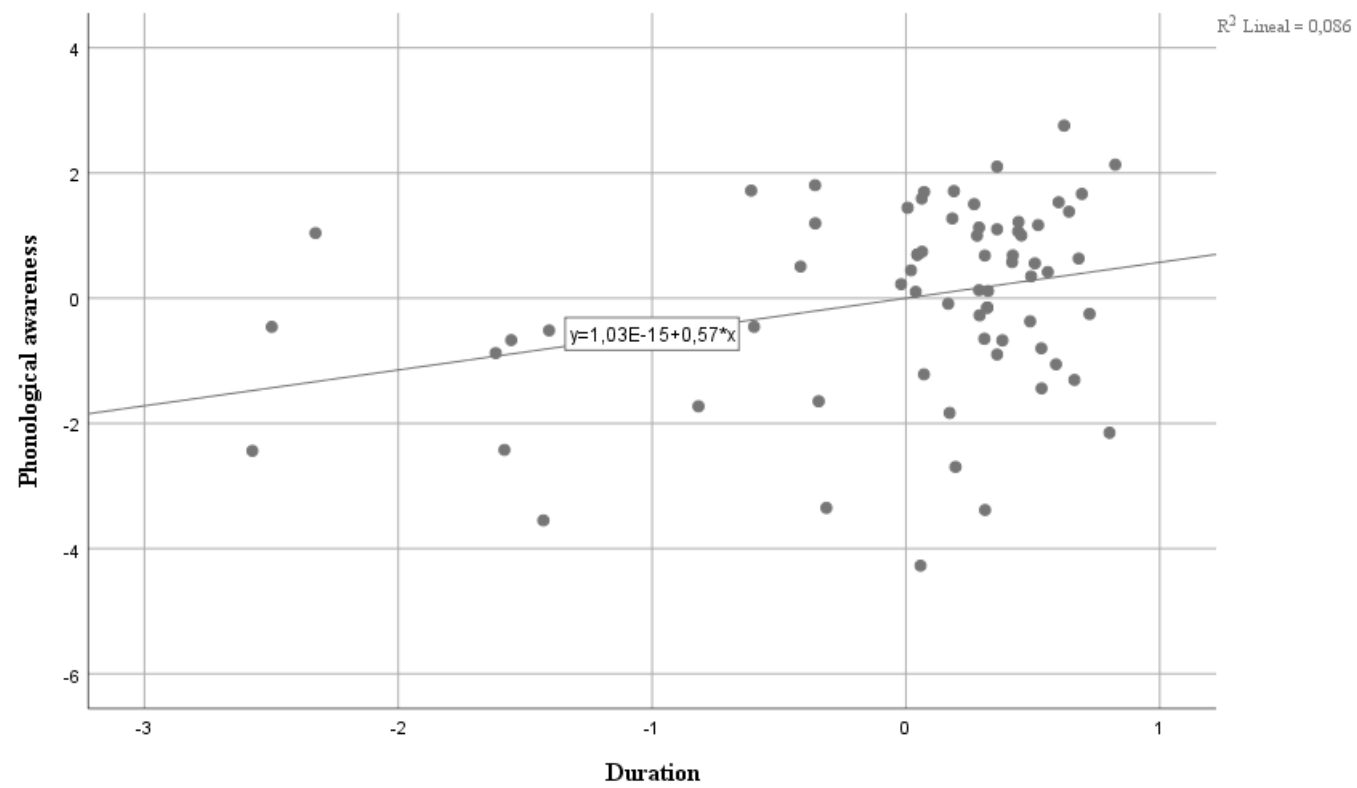

Graph 4. Phonological awareness and duration.

\section{Discussion}

This study supports the hypotheses that certain aspects of musical aptitude and phonological awareness of young foreign language learners share commonalities. Students with higher musical aptitude showed better phonological awareness skills. First of all, the general correlation can be noticed in Table 5 and 6 . However, simple regression analysis showed that comparing musical aptitude as a whole to phonological awareness covered only a $12.6 \%$ of the variability. Therefore, a multiple regression analysis which assessed each musical subdomain was needed.

These musical subdomains, as it has been discussed throughout this essay (Culp, 2017), are also connected. Phonological awareness results have been inferred by each musical subdomain as shown in Table 7. It evidences that tendencies are positive in pitch and duration, whereas in rhythm, loudness, timbre, and tempo, the results were not statistically significant. The explanation for this could lie on each the linguistic function of each item, since some of them are actually features of language while other not necessarily, that is to say, pitch and duration recognition are musical subabilites that are similar to phonological awareness, while loudness detecting does not share the same feature.

Although both show a positive relation, pitch is much clearer than duration, where results do not illustrate the tendency with such transparency. In relation to duration, it is well known that length is an essential phonetic feature in English language (New, Ferrand, Pallier \& Brysbaert, 2006). Therefore, it is logical to find a relationship between linguistic and musical recognition of duration, and so shows this paper.

Regardin pitch, we find ourselves in a similar scenario. English vowels have different frequencies (Kewley-Port, 1993) and positive relations between capability of detecting both linguistic and musical pitch variations were found in this study. Furthermore, if the amount of timbre exercises would have been larger, we would have probably found similar results, since, as instruments, vowel sounds also have their own sound quality. This agrees with Culp (2017, p. 332), who emphasizes the relationship between phonological awareness and pitch recognition.

On the other hand, loudness does not show a connection. It is true that pragmatic emphasis (which could be roughly defined as the addition of loudness to a certain part of an utterance) is an essential 
feature of pragmatic language (Fujisaki, 1988), but the pronunciation test measured only the pronunciation of isolated words, so relating loudness subdomain to phonological awareness based on the fact that pragmatic emphasis is similar to loudness recognition seems to be inaccurate.

Rhythm does not concern this type of loudness. It is usually connected to prosody, which is partially related to loudness (stressed syllables), but the rhythmical concept of language transcends the mere idea of loudness: words ${ }^{6}$ always have a stressed syllable, but prosody needs longer utterances to appear. In other words, it is difficult to perceive rhythm in an isolated word, since prosody addresses longer sequences. In relation to this, it is known that rhythm is an essential feature of language prosody, and empirical data has progressively been proposed (Patel \& Daniele, 2002), and rhythm is another musical aptitude subdomain that is usually related to phonological awareness by the scholars (Culp, 2017, p. 332). Theoretically speaking, we could expect a relation between rhythm and receptive pronunciation but, again, the phonological awareness test included isolated words only, which may be the reason why the results are not conclusive in this area. In the same line of thought, we do not see any point in drawing conclusions from the relation between tempo recognition and phonological awareness.

\section{Conclusions and pedagogic implications}

In this study, the relationship between foreign language (English) phonological awareness and musical aptitude was investigated. According to the results of our field research, in which 69 Spanish native primary school students participated, a proficient auditory capacity for music relates positively with its counterpart in pronunciation. This result agrees with Vangehuchten et al. (2015) and complements it: the relation has been proved positive both in adults and children. This would also concur with Besson (2017), which reported a positive correlation as well. In conjunction, judging by the obtained results, children that have good ear for music, have also good ear for pronunciation, apart from their previous musical nurturing (if any). However, we did not observe a relation between phonological awareness and all specific musical subabilites. This could mean that musical aptitude is not a homogeneous and inseparable group of capacities, since some of them seem to be more related to specific linguistic competences.

In addition, since no production was involved in this work, it could be interesting to complement Christiner \& Reiterer (2018) with the Spanish context regarding whether the connections between musical aptitude and language also affect young foreign language learners' productive skills.

Furthermore, it would be interesting to analyse some assumptions that consider jazz improvisation as a conversation (Weick, 1998), since informal surveys to musicians have also pointed out that people that use to play improvisation music appreciate many resemblances between both. Music improvisation tends to have some characteristics that remind us of verbal communication, as we have commented in the introduction of this essay. Therefore, due to the little research in this area, research could try to provide empirical evidence of this relationship. For instance, it could be designed as a pragmatic test about context, which assesses incoherent utterances for music and for pronunciation. Students would hear a linguistic utterance in a context, and they would have to decide whether it is coherent or not. For the musical part, a harmonic context could be provided, where a musical phrase sounded, and do the same procedure. If the musical phrase is off-tune or off-beat, the musical phrase would be considered incoherent.

Regarding teaching implications, the input of regular musical stimuli and more relevant inclusion of music into the educational music would foster language learning. Miyake (2004) already commented some experiences about students whose greatest demand about learning a new language was focused on pronunciation, and so is the case for study: pronunciation is highly

\footnotetext{
${ }^{6}$ More specifically, lexical words, due to the fact that grammatical words are very frequently unstressed (Hualde, 2009)
} 
demanded nowadays, since a very popular objective when learning a foreign language is to sound like a native speaker (Miyake, 2004, p. 75) and, in the end, being able to communicate in a practical way. However, this capability is obtained after years of practice, and in traditional learning, pronunciation is usually approached by boring drilling exercises (Miyake, 2004, p. 77), so musical approaches would not only help students' ear (which, as it has been shown, influences pronunciation), but also make those repetitive exercises more pleasant.

\section{Acknowledgments}

I would like to thank doctor $\mathrm{M}^{\mathrm{a}}$ del Carmen Fonseca Mora, whose assistance and assessment has been essential for the fulfilment of this study. Special gratitude to doctor María Gómez Domínguez, who provided the musical aptitude test, and methodologist Cristina Rodríguez Prada, who provided the statistics data for the analysis.

\section{References}

Besson, M., Barbaroux, M., Dittinger, E., (2017), Music in the brain: Music and language processing. The Routledge Companion to Music Cognition, 37-48. url: https://hal.archivesouvertes.fr/hal-01629324

Cantero, F. J. (2003)., Conceptos clave en lengua oral. In: Mendoza, A. Conceptos clave en didáctica de la lengua y la literatura. (pp. 25-39). Horsori. https://core.ac.uk/download/pdf/11168832.pdf

Chobert, J., Besson, M., (2013). Musical Expertise and Second Language Learning. Brain Sciences. 3, 923-940. https://doi.org/10.3390/brainsci3020923

Christiner, M., Reiterer, S., (2013). Song and speech: examining the link between singing talent and speech imitation ability. Frontiers in Psychology. 4 (874), 1-11. https://doi.org/10.3389/fpsyg.2013.00874

Christiner, M., \& Reiterer, S. M. (2018). Early influence of musical abilities and working memory on speech imitation abilities: study with pre-school children. Brain sciences, 8(9), 169. https://doi.org/10.3390/brainsci8090169

Culp, M. E. (2017). The Relationship Between Phonological Awareness and Music Aptitude. Journal of Research in Music Education. 65 (3), 328-346. https://doi.org/10.1177/0022429417729655

Fonseca-Mora, M.C.; Toscano-Fuentes, C. and Wermke, K. (2011). Melodies that help: The Relation between Language Aptitude and Musical Intelligence. Anglistik International Journal of English Studies, 22(1), 101-118. url: https://ssrn.com/abstract=1815339

Foncubierta JM, Machancoses FH, Buyse K and Fonseca-Mora MC (2020) The Acoustic Dimension of Reading: Does Musical Aptitude Affect Silent Reading Fluency? Frontiers in Neuroscience. 14:399. https://doi.org/10.3389/fnins.2020.00399

Gómez-Domínguez, M., Fonseca-Mora, M.C., Herrero, F., (2018). First and foreign language early reading abilities: The influence of musical perception. Psychology of Music. 1 (286), 1-12. https://doi.org/10.1177/0305735617746734

Gupta, C., Grunberg, D., Rao, P., \& Wang, Y. (2017). Towards automatic mispronunciation detection in singing. ISMIR. url: https://api.semanticscholar.org/CorpusID:28769969

Hansen, D., \& Bernstorf, E. (2002). Linking music learning to reading instruction. Music Educators Journal, 88(5), 17-52. https://doi.org/10.2307/3399821 
Hualde, J. I. (2009). Unstressed words in Spanish. Language Sciences, 31(2-3), 199-212. https://doi.org/10.1016/j.langsci.2008.12.003

Kang, H. J., \& Williamson, V. J. (2014). Background music can aid second language learning. Psychology of Music, 42(5), 728-747. https://doi.org/10.1177/0305735613485152

Kewley-Port, D., \& Watson, C. S. (1994). Formant-frequency discrimination for isolated English vowels. The Journal of the Acoustical Society of America, 95(1), 485-496. https://doi.org/10.1121/1.410024

Kempert, S., Götz, R., Blatter, K., Tibken, C., Artelt, C., Schneider, W., \& Stanat, P. (2016). Training early literacy related skills: To which degree does a musical training contribute to phonological awareness development? Frontiers in Psychology, 7, 1-16. https://doi.org/10.3389/fpsyg.2016.01803

Kuhl, P. K. (2004). Early language acquisition: cracking the speech code. Nature reviews neuroscience, 5(11), 831. https://doi.org/10.1038/nrn1533

Law, L. N. C, Zentner, M., (2012). Assessing Musical Abilities Objectively: Construction and Validation of the Profile of Music Perception Skills. PloS one. 7 (12), 1-15. https://doi.org/10.1371/journal.pone.0052508

Milovanov, R., Huotilainen, M., Välimäki, V., Esquef, P.A., \& Tervaniemi, M. (2008). Musical aptitude and second language pronunciation skills in school-aged children: neural and behavioral evidence. Brain research, 1194, 81-89. https://doi.org/10.1016/j.brainres.2007.11.042

Milovanov, R. (2009). Musical aptitude and foreign language learning skills-neural and behavioral evidence about their connections. In ESCOM 2009: 7th Triennial Conference of European Society for the Cognitive Sciences of Music. url: https://urn.fi/URN:NBN:fi:jyu$\underline{2009411285}$

Milovanov, R., Pietilä, P., Tervaniemi, M., \& Esquef, P. A. (2010). Foreign language pronunciation skills and musical aptitude: A study of Finnish adults with higher education. Learning and Individual Differences, 20(1), 56-60. https://doi.org/10.1016/j.lindif.2009.11.003

Miyake, S. B. (2004). Pronunciation and music. Sophia Junior College Faculty Bulletin, 20(3), 80. https://citeseerx.ist.psu.edu/viewdoc/download?doi=10.1.1.605.173\&rep=rep1\&type=pdf

New, B., Ferrand, L., Pallier, C., Brysbaert, M. (2006). Reexamining the word length effect in visual word recognition: New evidence from the English Lexicon Project. Psychonomic bulletin \& review, 13(1), 45-52. https://doi.org/10.3758/BF0319381

Patel, A. D., \& Daniele, J. R. (2002). An empirical comparison of rhythm in language and music. Cognition, 87(1), B35-B45. https://doi.org/10.1016/S0010-0277(02)00187-7

Pei, Z., Wu, Y., Xiang, X., \& Qian, H. (2016). The effects of musical aptitude and musical training on phonological production in foreign languages. English Language Teaching, 9(6), 1-29. https://doi.org/10.5539/elt.v9n6p19

Peynircioglu, Z. F., Durgunoglu, A. Y., \& Úney-Küsefog`lu, B. (2002). Phonological awareness and musical aptitude. Journal of Research in reading, 25(1), 68-80. https://doi.org/10.1111/1467$\underline{9817.00159}$

Posedel, J., Emery, L., Souza, B., \& Fountain, C. (2012). Pitch perception, working memory, and second language phonological production. Psychology of Music, 40, 508-517. https://doi.org/10.1177\%2F0305735611415145

Vangehuchten, L., Verhoeven, V., \& Thys, P. (2015). Pronunciation proficiency and musical aptitude in Spanish as a foreign language: results of an experimental research project. Revista de Lingüística y Lenguas Aplicadas, 10(1), 90-100. https://doi.org/10.4995/rlyla.2015.3372 
Weick, K. E. (1998). Introductory essay-Improvisation as a mindset for organizational analysis.

Organization science, 9(5), 543-555. https://doi.org/10.1287/orsc.9.5.543 